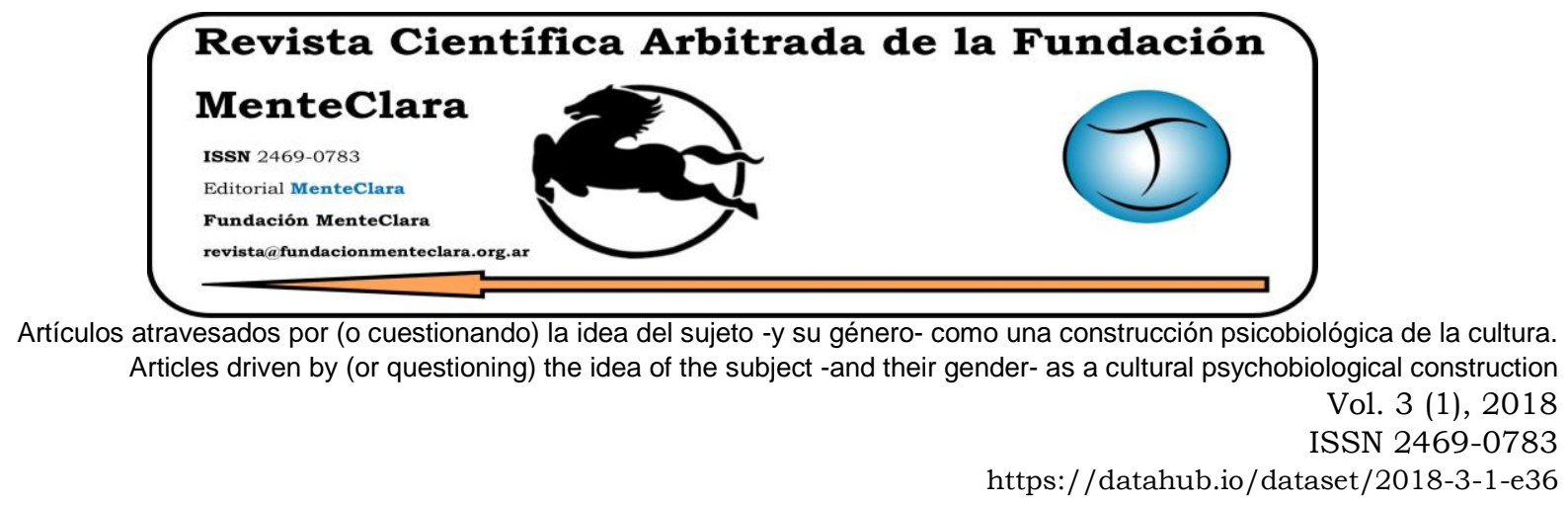

\title{
ECO-ETHICAL VIEWS OF TAGORE AND AMARTYA SEN
}

\section{OPINIONES ECOÉTICAS DE TAGORE Y AMARTYA SEN}

Ratan Lal Basu rlbasu@rediffmail.com

Presidency College, Calcutta \& University of Calcutta, India.

Cómo citar este artículo / Citation: Basu R. L. (2018). " Eco-Ethical Views of Tagore and Amartya Sen". Revista Científica Arbitrada de la Fundación MenteClara, 3(1), 31-42. DOI: $10.32351 /$ rca.v3.1.39

Copyright: () 2018 RCAFMC. Este artículo de acceso abierto es distribuido bajo los términos de la licencia Creative Commons Attribution-Non Commercial (by-cn) Spain 3.0. Recibido: 28/02/2018. Aceptado: 26/03/2018 Publicación online: $30 / 04 / 2018$

Conflicto de intereses: Ninguno que declarar.

\begin{abstract}
Ever since the Nobel Prize in Economics was awarded to Amartya Sen, there has been much endeavour to highlight Sen's Shantiniketan background and affinity of his world outlook with that of Rabindranath Tagore. Unfortunately, a deeper analysis is likely to reveal that Amartya Sen's views (based on western world-outlook) are diametrically opposed to that of Tagore (based on ancient Indian world-outlook), particularly as regards sustainable development and eco-ethical human living. This article endeavours to highlight these contrasting aspects of the world-outlooks of two Bengali Nobel Laureates.
\end{abstract}

\section{Resumen}

Desde que se otorgó el Premio Nobel de Economía a Amartya Sen, se han hecho muchos esfuerzos por destacar el pasado de Sen Shantiniketan y la afinidad de su visión mundial con la de Rabindranath Tagore. Desafortunadamente, es probable que un análisis más profundo revele que los puntos de vista de Amartya Sen -basados en 
el mundo occidental- sean diametralmente opuestos a los de Tagore -basado en la antigua perspectiva india mundial-, particularmente en lo que respecta al desarrollo sostenible y la vida ética humana. Este artículo se esfuerza por resaltar los aspectos contrastantes de las visiones del mundo de dos galardonados con el Premio Nobel de Bengala.

\section{Palabras Claves/ Keywords}

Tagore-vs-Amartyasen; eco-ethics; humanitarian-vs-market-oriented; Rabindranath Tagore; Sen Shantiniketan; Amartya Sen; ecoética; Nobel 


\section{Tagore on Eco-Ethical Human Living}

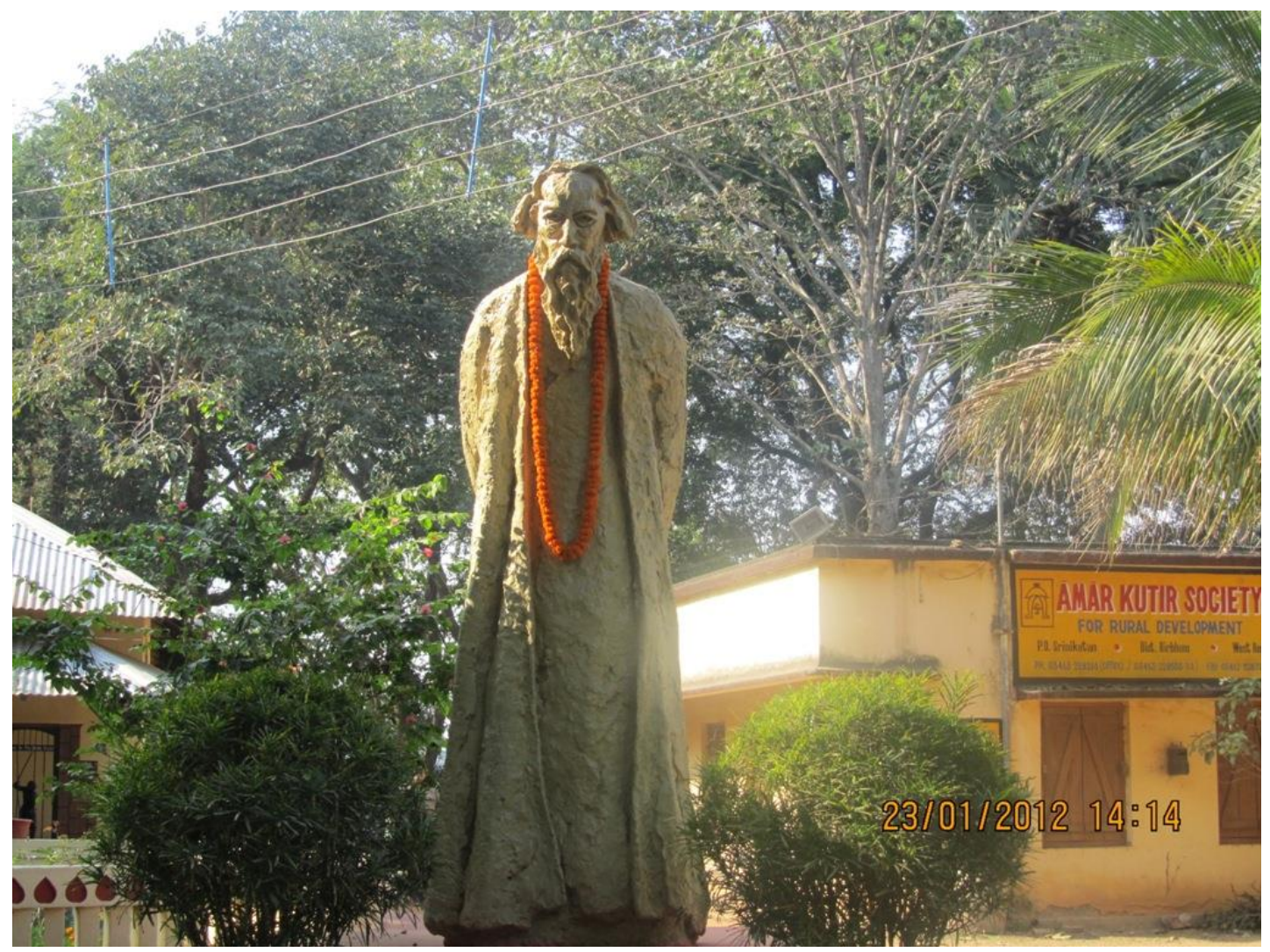

Rabindranath Tagore's views pertaining to eco-ethical human living and sustainable development, as scattered in various works -a list is given under References at the end of the article-, are based on ancient Indian philosophy, especially embedded in the Upanishads. Tagore considers Nature and human life as integral parts of the single entity, the omniscient, omnipresent, ubiquitous -sarbang khallidang-, attribute-free -nirguna- Brahman. So Tagore emphasizes symbiosis and balance between man and all other aspects of the mundane world -plants, other living beings, the Earth, atmosphere and the rest of the universo-, and between man and the world beyond -moksha-.

In 'Aranya Devata', (Forest Deity: R. R. Vol.14, P.373) Tagore opines that modern man indulges, too much in luxurious and profligate living. So long as he used to live in and around the forest, he had deep love and respect for the forest and therefore he used to live in perfect symbiosis 
with it and the plants and animals inhabiting it. As soon as he became city-dweller, he lost his love for forest which had been the source of his sustenance. Wanton destruction of forest, in order to supply timber for the city life, brought about curse on human race. Paucity of rainfall endangered human life and rapid spread of deserts started engulfing human habitations in various parts of India. So, Tagore emphasizes, we are to retrieve our love and respect for the forest and restore symbiosis with the forest in order to avert peril.

Tagore's views on ecological stability and symbiosis between man and Nature have been elaborated in the article 'Tapavan' (R. R. Vol. 7, PP. 690-704). The great philosopher-poet does not confine his analysis to the outward manifestations of ecological imbalance alone. He investigates the inner cause of this malady which springs from the ripus -the basic viceslike greed, jealousy, pride, lust, sheltered in the dark grooves of human mind. These ripus have their ugly manifestations in commercialism, consumerism and unbridled competition. In the article 'Bilases Fans' (the noose of luxurious living: R. R. Vol. 6, PP.526-530), Tagore opines that consumerism, which has been eating into the vitals of western societies, is now making inroads into Indian lifestyles vitiating all spheres of Indian life. The motive of insatiable personal consumption has made people in our country lose their social entity and philanthropic attitude and has made most of them mean and self-centered. Pomp and conspicuous consumption is not a new thing in India. At earlier times, however, it was associated with social activities, but now it is centered on purely personal consumption in isolation from the society. Consumerism is not only generating pressure on the purse of the rich but also causing unimaginable hardships to the poor who, being enticed by demonstration effect, are trying to spend beyond their means. 
Tagore opines (R. R. Vol. 6, P. 529) that revelation of dazzling riches in some parts of the country is making a false impression that this signifies economic prosperity. Unfortunately, this is not due to prosperity, but due to increasing concentration of wealth in the hands of a few at the cost of the majority.

Tagore unravels the perverse impact of the unbridled competition in 'Bharat Varsha' (R. R. Vol. 2, P. 711): The motive of competition, which forces one into a mad race for outclassing all other persons around him., leads one to an endless struggle for supremacy and deviates him form the path of responsibility and ethical living. The demonic impulse for going farther and farther ahead knows no limit and makes one's mind ever restless and bereft of stability and peace. Tagore expresses pity for those who consider this mad race as prosperity.

In contrast, Indian society, Tagore holds, was based on universal welfare and symbiosis between man and man, and it had never encouraged this self-destructive competition leading to infighting within human society for individual supremacy.

In 'Samabaya Niti' (cooperative policy: R. R., Vol. 14, PP. 311-332), Tagore expresses the view that European society is based on the system of exploitation of the majority by the minority, which is one of the major evil outcrop of unbridled competition and the motive of unabashed selfadvancement. Tagore, however, admits that motive of self-advancement and competition, within some limit, are necessary for the material progress of human society, but they are perilous for human society if the limit is crossed.

Thus, according to Tagore, eco-ethical human living should be based on symbiosis between man and Nature, and between man and man. But manifestations of ripus through limitless competition, consumerism and 
commercialism have undermined this symbiosis alarmingly in the modern era. Unless the trend is reversed and objective conditions for ecoethical human living restored, the consequences would be disastrous.

\section{Tagore on Sustainable Development}

Tagore's concept of sustainable development of India is rooted deep in rural regeneration as majority of the population of India reside in villages. It has two major planks:

I) Cooperatives and II) Panchayats.

In both the cases, Tagore calls for revival of the spirit of the rural masses so that they could be self-sufficient and free from dependence on outside assistance -'to approach the authorities with begging bowls' so to say- for their economic and social uplift and empowerment. Tagore lays greatest stress on instilling the spirit of self-confidence and unity in the minds of the rural folk -through proper education- so that they could, on their own, fight off the maladies afflicting rural India.

If cooperatives and panchayats are thrust on the rural folk from without (say, by the government, political parties or vested interest groups), they would miserably fail to generate and support the process of sustainable development, which is possible, Tagore holds, only by inspiring the rural masses to form cooperatives and panchayats by their own efforts.

In 'Samabaya Niti' (ibid.), Tagore attributes agricultural backwardness in India to subdivision and fragmentation of agricultural plots, problems of marketing, storing and mechanization of small farmers, lack of finance and exploitation by money lenders etc. Tagore thinks that all these problems could be solved through cooperatives. He further emphasizes that the root cause of rural destitute is the lack of self-confidence of the 
rural people, which makes them dependent on outside help, especially from the government. So, our primary task is to make the rural folk aware of their own strength, which lies in unity. Tagore stresses: "For this reason, the most urgent need in our country is not to place begging bowls at their hands, but to make them confident of their own power, to make them realize that a man united with others is a complete entity, whereas an alienated individual is but a powerless fragment." (R. R. Vol. 14, P.313)

Coming to panchayats, Tagore, in 'Atmashakti' (self-power: R. R. Vol. 2, P.644), opines that rural panchayat system imposed by the government would be a miserable failure. It would breed jealousy and infighting among rural masses for the coveted panchayat posts and would generate more problems than it would solve. The members of the panchayats would be interested in serving more the government officials -to gain favor- than their rural brethren. They would virtually become instruments at the hands of the government to repress rural people. Panchayat system, which was a real source of power of the rural people of India in earlier times, would now become a cause of disunity and weakness of the rural masses. They ought to form panchayats on their own.

Tagore always encourages the application of modern technologies for rejuvenation of rural India, but all these should be within the framework of a regenerated rural society based on self-help and freedom from outside interference.

\section{Views of Amartya Sen}

Amartya Sen's world outlook pertaining to eco-ethical human living and sustainable development, notwithstanding his Shantiniketan background, springs from western paradigms. His major works bear 
testimony to that fact that unlike Tagore he treats ecology and sustainable development as extraneous elements amenable to treatment within the framework of market mechanism. Sen treats in detail the problems associated with environment and ecology (Sen, 1982, PP.67-68; 1984, PP.95-97; 1995, PP.211-216) in the light of western paradigms associated with market mechanism, individual choice and Game Theory. This would be clear from the following excerpt: "Suppose it is the case that there are strong environmental reasons for using glass bottles for distributing soft drinks (rather than single-used steel clans) and for persuading the customers to return the bottles to the shops from where they buy these drinks -rather than disposing them off in the dustbin-. For a relatively rich country the financial incentives offered for returning the bottles may be adequate if the consumers neither worry about the environment nor are thrilled by receiving back small change. The environment affects the life of all, true enough, but from the point of view of any individual the harm that he can do to the environment by adding his bottles to those of others will be exceedingly tiny. Being generally interested in the environment but also being lazy about returning bottles, this person may be best of if the others return bottles, next best if none does, and worst of all if he alone returns bottles while others do not. If others feel in a symmetrical way we shall then be in a prisoner's dilemma type situation in which people will not return bottles but at the same time all would have preferred that all of them should return bottles rather than none. To tackle this problem, suppose now that people are persuaded that non-return is highly irresponsible behaviour and while the individuals in question continue to have exactly the same view of their welfare, they fall prey to ethical persuasion, political propaganda or moral rhetoric. The welfare functions and the preference relations are still exactly the same and all that changes is behaviour. 
"I am not, of course, arguing that a change in the sense of responsibility is the only way of solving this problem, penalizing non-return and highly rewarding return of bottles are other methods of doing this. ...The real difficulty arises when the checking of people's actions is not easy." (Sen, 1982, PP. 67-68)

Sen's view regarding cooperatives is:

"In many countries, the main rural institutions set up by the administration and the political system have taken the form of cooperative structures...........It is not exaggeration to say that rural cooperatives, far from being partners of pressure groups with which the government has to negotiate, are in fact the lower elements of the state apparatuses." (Sen, 1995, P. 536)

Although Sen's observation is related to Africa, the miserable outcome observed is perfectly in line with predictions made long ago by Tagore in case of Indian cooperatives imposed from above by the government.

Unfortunately, Sen fails to unearth the real cause of failure of the cooperatives and attributes it, erroneously, to colonial legacy and technological backwardness. As solution he prescribes:

"More precisely, Africa has no choice but to generate and diffuse technological progress at a rate sufficiently rapid to cause regular increase in land productivity.......

"From the above list of factors it is evident that the problems which Africa has to solve in order to trigger off new growth and development impulses in her agricultural sector do not lie wholly in technological sphere. Changes in institutions and in the cultural and political systems will also be 
required. Moreover, it is worth, stressing that the levels of income and the food security of the small holder majority in Africa will not be improved unless serious attention is paid to equity issues and distributive effects of agricultural growth-promoting strategies." (ibid. PP. 542-43)

Thus Sen's way out comes down to technological changes and policy measures from outside. The question of moral regeneration of the rural masses is totally ignored. This is also evident from his technical model building in 'Resources, Values and Development' (Sen, 1984, PP. 37-89)

In 'On Economic Inequality' (Sen, 1973), 'Poverty and Famines' (Sen, 1981) and 'Hunger and Public Action' (Sen, 1989) Amartya Sen has endeavoured to investigate the causes of human deprivation (as regards basic amenities like food, nutrition, healthcare, education, women's rights etc.) and assessed them in terms of 'entitlements' and 'capabilities'. Later on various Human Development Indices (HDIs) have been constructed by the Pakistani economist Mahabub Ul Haq and the United Nations Development Program (UNDP) on the basis of concepts of Amartya Sen, who classifies human deprivation into three major categories:

I) Those caused by uncontrollable natural calamities like earthquakes, cyclones.

II) Those caused by the inherent vices of the sufferer.

III) Those caused by bad governance, social injustice and economic exploitation of the majority by the well-to-do minority.

Amartya Sen emphasizes the third category, whereas Tagore's stress is on the second. In an exchange based economy, a man collects his basic amenities through the basic capability, i.e. income ('exchange entitlement' to use Sen's jargon). Sen deals with in detail various human 
deprivations resulting from lack of capabilities and entitlements. These are the basis of all deprivation indices constructed later on by Haq (Haq, 1997), UNDP etc. The spirit of the viewpoints in this regard of Amartya Sen and his followers is that policies of the governments of different LDCs and those of the world bodies -World Bank, IMF.- are to be reoriented to eradicate human deprivation in various parts of the globe.

So, in essence, they propose that these authorities are to fill the begging bowls of the deprived, the approach most abhorred by Tagore.

From the above discussion it becomes clear that the endeavour to trace Tagore's world outlook in Amartya Sen's works pertaining to ecoethical human living and sustainable development, cannot stand close scrutiny. Tagore's world outlook springs from views embedded in the Upanishads, whereas Sen's draws his concepts from the western paradigms. 


\section{Notes}

Tagore, R. Rabindra Rachanavali (R. R.), 125th Anniversary Edition, 1986, Visva-Bharati Publishers, Calcutta-17

I) Vol. 2: Atmashakti, P. 617; Bharat Varsha, P. 695

II) Vol. 6: Swadeshi, P. 497; Samaj, P. 517; Bilaser Fans, P. 526; Shiksha, P. 563

III) Vol. 7: Dharma, P. 447; Shantiniketan, P. 521; Tapavan, P. 690

IV) Vol. 14: Samabaya Niti, P. 309; Palli Prakriti, P. 351; Aranya Devata, P. 372

\section{References}

Haq, Mahbub U1 (1997): Human Development in South Asia. Oxford University Press (OUP), New Delhi in 1997

Sen, Amartya (1973) On Economic Inequality. Oxford University Press (OUP), New Delhi in 1999

Sen, Amartya (1981) Poverty and Famine. Oxford University Press (OUP), New Delhi in 1999

Sen, Amartya (1982) Choice, Welfare and Measurement, Oxford University Press (OUP), New Delhi in 1999

Sen, Amartya (1984) Resources, Values and Development. Oxford University Press (OUP), New Delhi in 1999

Sen, Amartya \& Dreze, J. (1989) Hunger and Public Action. Oxford University Press (OUP), New Delhi in 1999

Sen, Amartya (1995) The Political Economy of Hunger.

Tagore, R. Rabindra Rachanavali (R. R.), 125th Anniversary Edition, 1986, Visva-Bharati Publishers, Calcutta-17 